\title{
Socio-Economic Issues and Land Degradation in Fai Environs of Jaba Local Government Area of Kaduna State-Nigeria
}

\author{
Ajibuah Bolanle Joel Phd \\ Department Of Geography Faculty of Arts And Social Sciences Nigerian Defence Academy Pmb 2109 Kaduna \\ Kaduna State-Nigeria
}

\begin{abstract}
Land degradation is one of the critical environmental challenges confronting our contemporary world. This scenario is becoming more intensive, grievous and is further compounded by economic and political morasses that are accentuated by monumental intra-generational gap and obliviousness of the people of the consequential implications of their actions particularly in the rural communities of Nigeria. This development unmitigated has tendency to aggravate intergenerational unsustainability of the natural resources. The most affected environment is the arable land, the main source of economic activity of the people. Thus unabated excavation of the topsoil has high propensity and multiplier effect to endanger unimaginable crises in the future. Participatory approaches were used in data collection processes and pictorial descriptive analyze technique employed for presentation of findings. This paper discovers the craving desire of community people for property ownership such as residential houses, income for daily sustenance enhances topsoil excavation and environmental degradation of Fai and its immediate communities. This paper emphasized unreservedly the tendencies of these basic needs if not properly managed consciously and alternative such as vocational and lifebuilding skills of the people built could heighten community poverty and proliferation of environmental degradation in the nearest future. The paper therefore, suggests the urgent need for community driven participation in afforestation programming that will checkmate these degradation activities through mobilization, awareness creations and sensitization of all stakeholders, duty-bearers and right-claimers on behavioral and attitudinal change. Also, the government has to formulate empirical, workable and incisive interventional policy to save the unacceptable prevailing and deplorable situation of the environment.
\end{abstract}

Keywords: Land degradation, environment, and soil excavation

\section{Introduction}

Land degradation is the most important environmental problem currently challenging the notion of sustainable development in many parts of the world. It is a process of decay in the land's physical and biological resources, which continues until it reduces the land's advantages. The process can be natural but it usually ends with a new natural imbalance. In most of the recent cases, land degradation reflects imbalance between human and environment. Human factor is always seen not as the trigger but the accelerator of the land degradation process so that the land becomes truly unproductive and difficult to rehabilitate, limited by time and cost. Thus, the land can be viewed as a component of ecosystem interacting with many other components to create a dynamic balance within certain limits. However, human being can influence the balance when basic needs for live sustenance are threaten. Although certain limits also, ecosystem can sustain pressure caused by this influence and not degrade within a certain time frame. But should the pressure be continuous, however, the ecosystem supporting power will overload and there will be on-site and offsite forms of degradation. This consequential problem is most acute where the environment is intrinsically vulnerable and where the people are craving for survival in an economy bedeviled by economic morass, poverty at various rung of lives, thus losing control of its own resources unconsciously and with gross insensitivity is concomitant leverage for peoples' survival.

\section{Conceptual Framework And Degradation Specification}

Land degradation means reduction or loss of the biological or economic productivity and complexity of rain fed cropland, irrigated cropland, or range, pasture, forest and woodlands resulting from land uses or from a process or combination of processes, including processes arising from human activities and habitation patterns, such as: soil erosion caused by wind and/or water; deterioration of the physical, chemical and biological or economic properties of soil; and long-term loss of natural vegetation (FAO: 2007). This means that land degradation primarily relates to a reduction in soil quality and quantity as an input to the production of agricultural crops. This description reiterates that land degradation can be sum-up as a major threat and a leading to the loss of; the vegetative cover, productivity value and biodiversity as well as causing soil erosion. 
Suffice to say that the overtime contributions to the environmental security debate, land degradation is frequently argued to constitute a future both inter or intra generational major threat. This is one of the crux issues extensively deliberated upon since the International Cairo Population Development 1994 Programme of Action recognized that the inter-relationships between population, sustained economic growth and sustainable development (Population Reference Bureau International, 1995). As it mentions, demographic factors, combined with poverty and lack of access to resources in some areas, and excessive consumption and wasteful production patterns in others, cause or exacerbate problems of environmental degradation and resource depletion. This malaise of uncontrollable population explosion and proportional increase of peoples' poverty level continuously reinforces unsustainable use of natural resources and environmental degradation consequences.

It is no doubt that World food production has increased and we should not be deceived by the more food per capita availability now than ever before in world history. But what is pertinent and germane to know is the increasing scarcity and degradation of agricultural and other environmental resources with such efforts which invariably cast serious doubt as to how long food production experiencing can equilibrate population growth. Throughout the world, many fragile, biologically unique ecosystems and the many species of plants and animals they contain are threatened. Fresh water is already in short supply in some regions and future population growth will increase the pressure on this renewable, but limited resource (Scherr, 1999).

It is on this onus that issue of globalization, and new and emerging technologies and modes of production and consumption, the relationships among population, environment and development should be of heighten concern to all sundry so as to safeguard the environment during the twenty-first century and beyond.

The world known and reference Commission on Environment and Development of Brundtland Commission in Evenson et al (2003) reiterates the fact that figuring profits from logging rarely takes full account of the losses in future revenue incurred through degradation of the forest. Similar incomplete accounting occurs in the exploitation of other resources, especially in the case of resources that are not capitalized in enterprise or national accounts; air, water and soil. In all countries, rich or poor, economic development must take full explanation in its measurement of growth of the improvement or level of deterioration in the stock of natural resources

In a similar disposition Henao et al (2006) emphasizes the need of natural resource discourse, its empirical and situational analysis as it relates to usage to socio-economic means to livelihood ends. This is because of its multiplier effects as natural resource loss directly affects national productivity, resources creation and national income. Ecology and economy is intricately related. Any loss in ecology must hamper economic prosperity. Therefore, natural resource situation analysis is mandatory for sustainability of development.

During the last half-century the global extent of agriculture has increased vastly at the expense of natural forests, rangelands, wetlands, and even desert. Some of the increased land degradation associated with this expansion is compensated by farmers' investment in soils, such as fertilization, terracing, and tree-planting. New soil formation also occurs through natural processes, but in general these proceed too slowly to compensate for human-induced degradation (Olderman et al, 1991). For instance, more than 25 years ago the world's croplands have commenced serious decline due to the pressure of human activities. This is evidence of the first global survey of soil degradation carried out by the United Nations (1996) revealed that human-induced soil degradation, has shown significant problems in virtually all parts of the world, obviously for example, human population and cropland area shown a steady decline from 1961 to 1991, amounting to a decrease of between 20 and 30\% especially in South America croplands have declined at a rate that is slower than the global average, while African per capita croplands have declined at a greater than average rate.

A critical spatial analysis of the global location of natural and human made factors of land aridization and soil degradation shows that the arid zone of the world covers about $40 \%$ of the world's land surface and has about $13 \%$ of the world population. Arid and semi-humid areas together comprise about $50 \%$ of the world's land and $25-30 \%$ of its population. The 55-65 countries located in the arid and semi-humid zone are subject to regular or periodic aridity, xerotization, drought, and to the phenomena of wind erosion, soil degradation, salinity, alkalization, and soil compaction (Sjaatad, et al 1997). Inductively, human interplay aridization processes if unchecked will further increase the spatial coverage of arid zone of the world at an increasing rate and at a shorter period of time.

In spite this vulnerability no developing country has installed a system for monitoring soil quality at a national scale. Existing assessments are based on consultation with experts, extrapolation from case studies, field experiments and other micro studies, or inferences from land use patterns (Scherr, 1994). While little is known about current status, even less is known about trends, and to what extent the degradation processes are human-induced. This is the pivot of this study revelation although still at micro level. 
Within specific agro-ecological environments, experimental data from plot and field scale allow soil degradation processes to be observed with greater precision. Long-term data series indicate that intensive topsoil misuse can cause yield reductions of 50\% and more in some environments (Eswaran et al, 2006).

Even under best varietal selections and management practices, yields have stagnated and even fallen under long-term intensive usage (Cassman, 1996 and Kim, et al 2000). Furthermore, a review of Scherr (1999) of 16 studies to assess the global extent, rate, and effects of soil degradation concluded that soil quality on three quarters of the world's agricultural lands has been fairly stable over the last fifty years, but that on the remaining share land degradation is widespread and has accelerated. Productivity has declined substantially more than $16 \%$ of agricultural land in developing countries, especially crop land in Africa where million hectares of land areas have gone out of production each year. These are primarily lands at the margin of cultivation, especially at desert margins and in steeply sloping and high-altitude areas.

Thus, soil nutrient mining is particularly acute in Africa. In 2002/2004 about $85 \%$ of African farmland had nutrient mining rates at more than $30 \mathrm{~kg}$ nutrients (NPK) per hectare per year, and $40 \%$ had rates greater than $60 \mathrm{~kg} / \mathrm{ha}$ yearly (Henao et al 2006). Partly as a consequence, Sub-Sahara African cereal yields are the lowest in the world, averaging about one ton per hectare - about the same as 20 years ago. Although, patterns of degradation vary according to agro-ecological conditions, farming systems, levels of intensification, and resource endowments, but these also interact in important ways with social and economic systems. In the tropical and subtropical marginal lands, which have low physical resilience to land degradation, and are also associated with societies in which property rights are weakly defined, information systems are weak, and managerial capacity is low. For poor people, income from land accounts for a larger share of total income, thus making them more vulnerable to degradation. They also have fewer resources for alleviating degradation, and are especially susceptible to the credit market failures and land tenure insecurity, which can raise time discount rates and reduce planning horizons, leading to faster soil mining. These describe the study area that is very germane for in-house examination before the externalities of actions takes its tolls on the vulnerable and helpless poor people.

The aforementioned scenarios described perfectly the situations and circumstances of proliferation of land degradation processes in the study area. This is an area known for the highest cultivation and production of high quality Ginger in Sub-Saharan Africa. This paper therefore, presents the situational and empirical analysis of the degree of degradation ravaging the area, a process that is ongoing that has capabilities to lower the current and future carrying capacity of the soil potentialities in supporting agricultural activities of the people if urgent intervention are not given to this human-induced phenomenon against the natural arable land.

\section{Methodology: Participatory Approach}

A participatory approach was employed in the study through the conduct of field level stakeholder meetings, consultations, and focus group discussions with local communities, were designed to gather information about the local livelihoods and rural production systems. First, a historical study of Fai and its immediate environment was undertaken to understand its historical setting. We traced the communal peculiarity and configuration that happened at a particular time. Secondly, a transect walks with communities youth and ward leaders as local guide enabled us to observe, ask questions, listen to, discuss and learn about different features of the village terrains and human activities that have unfolded over a period of time and have affected the vegetation, crops grown, source of livelihood, and first-hand information on local technologies for soil excavation and exploration of precious stones spots identification. The data sought and obtained were pictorially captured and analyzed.

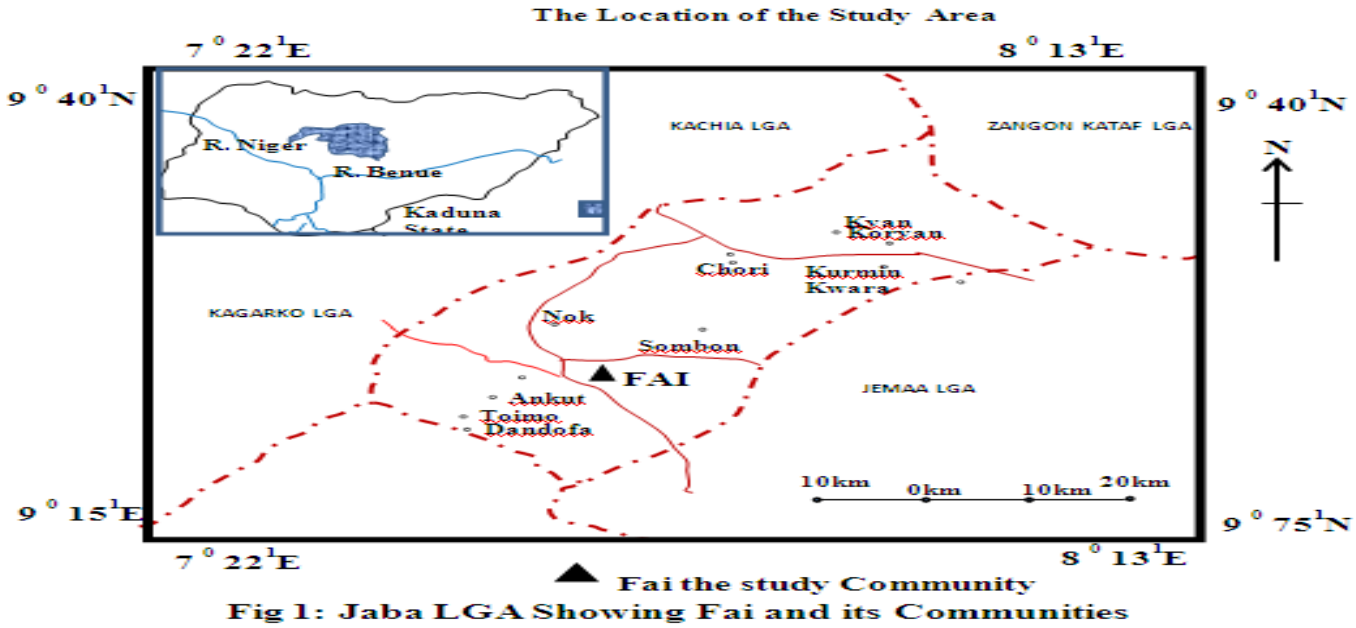


For spatial location, Fai can be described relatively to its Local Government Area, Fai and its immediate environs are situated between longitude $9^{0} 75^{1} \mathrm{~N}$ and $9^{0} 40^{1} \mathrm{~N}$ and latitude $7^{0} 22^{1} \mathrm{E}$ and $8^{0} 13^{1} \mathrm{E}$ in Jaba Local Government Area of Kaduna State. The LGA is bordered by the following Local Government Areas: Zangon Kataf to the Northeast; Kachia to the Northwest; Jema'a East, and Kagarko to the West (See Fig. 1). It has 155, 973 population (National Population Census, 2006). The Jaba communities/settlements are predominantly rural, engaging mainly in agricultural activities with Jaba and Yaskwa formed the major ethnic groups.

\section{Results And Discussion}

The various human activities enhancing soil degradation are presented in pictorial forms. This is used to illustrate various land degradation situation as it relate to types, causes, and implication on the flora and fauna of the physical environment.

\section{Types And Causes Of Land Degradation}

The major causes of top soil excavation in this area is that soil serves as the main source of income generation, accessible and cheaper raw material for building residential houses in the communities. This is shown in Plates 1 to 10

i. Category of Income Generation and Source of Raw Material for Residential and Domestic Animal Houses Building

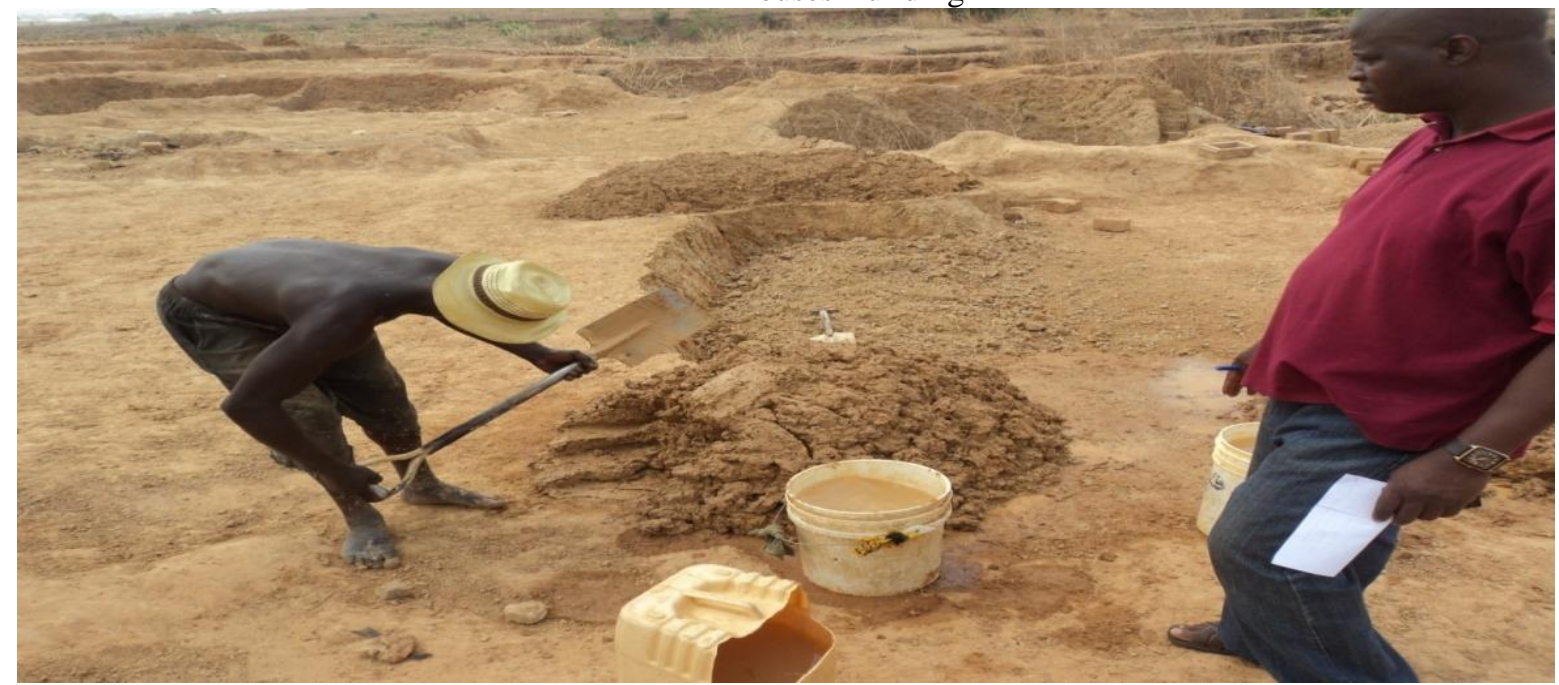

Plate 1. Illustrate mixing procedure for brick making

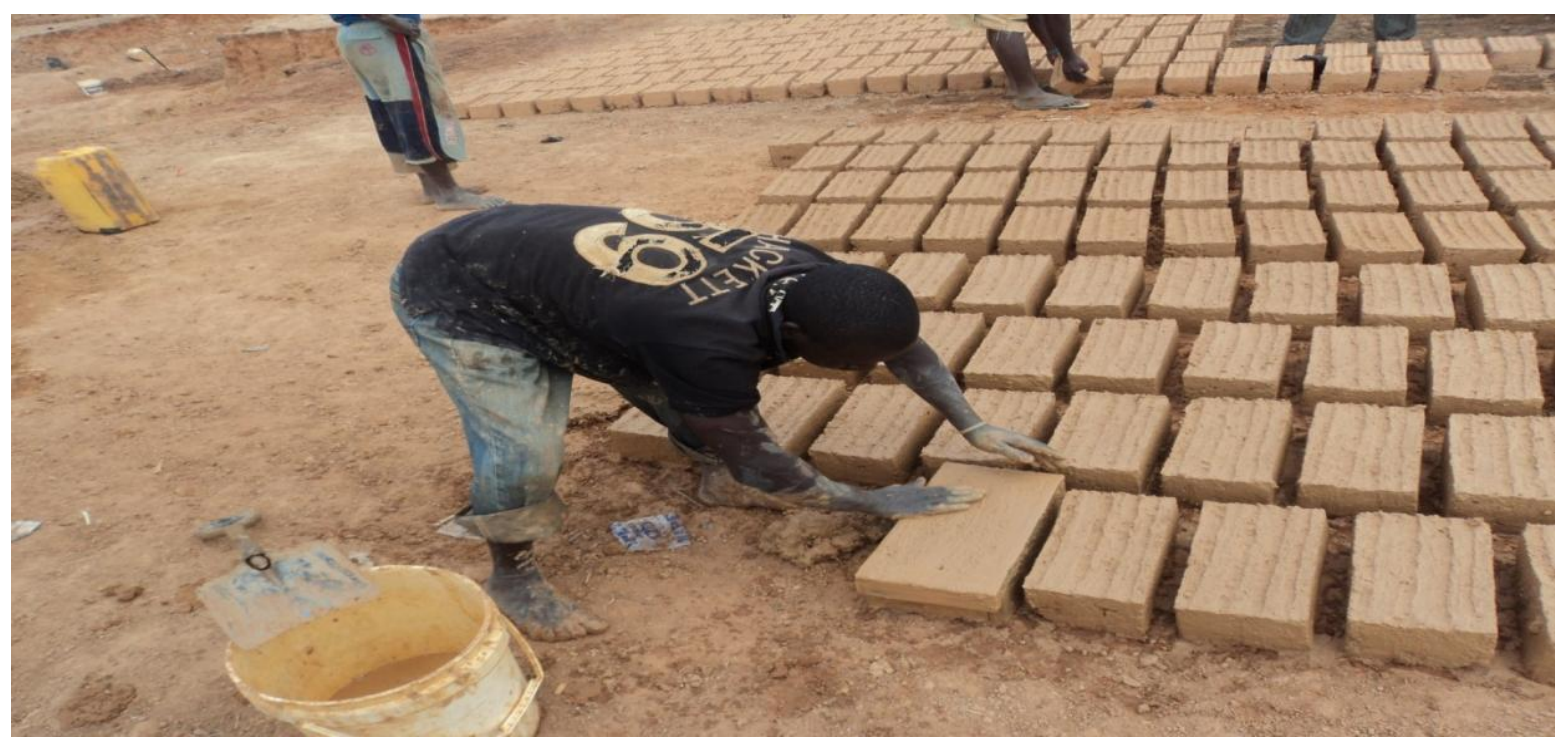

Plate 2. Molded bricks at final stage of production 


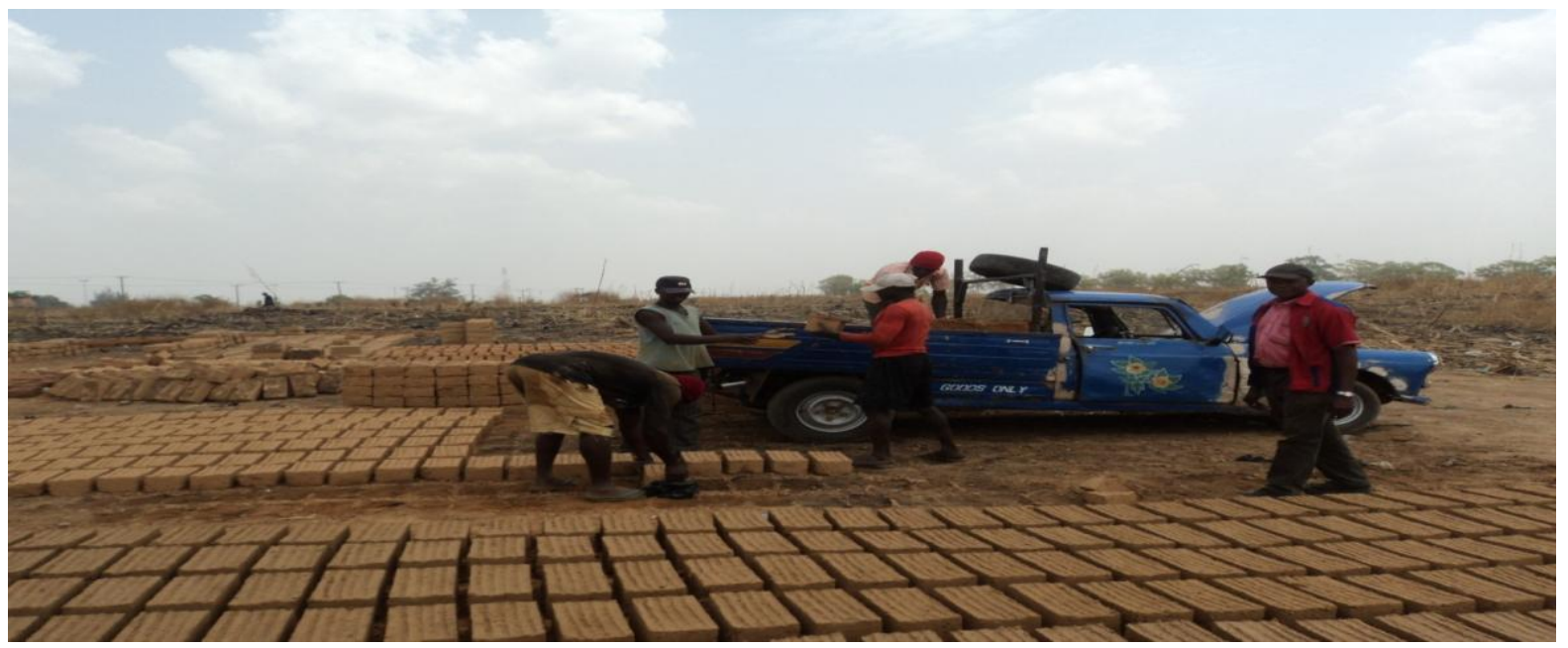

Plate 3. Drying and sales point

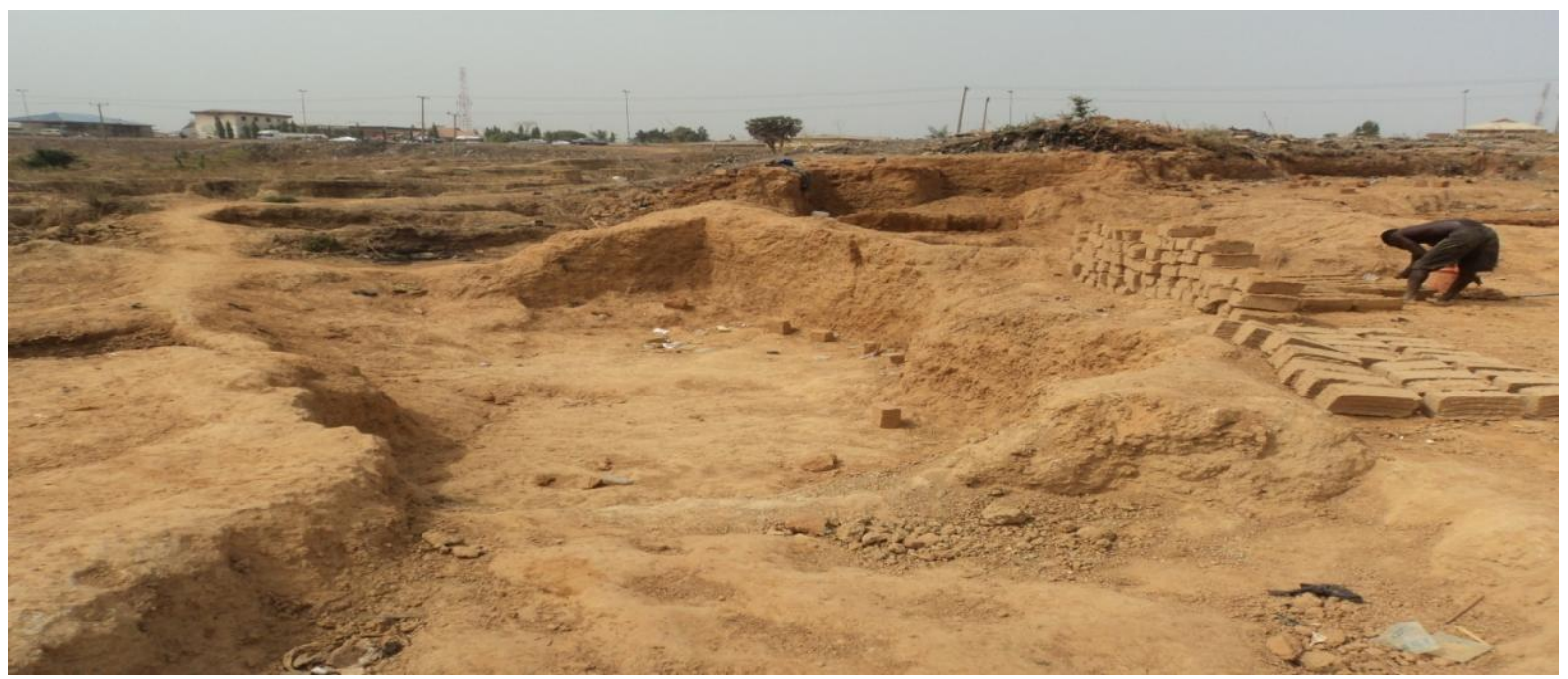

Plate 4. Excavated area

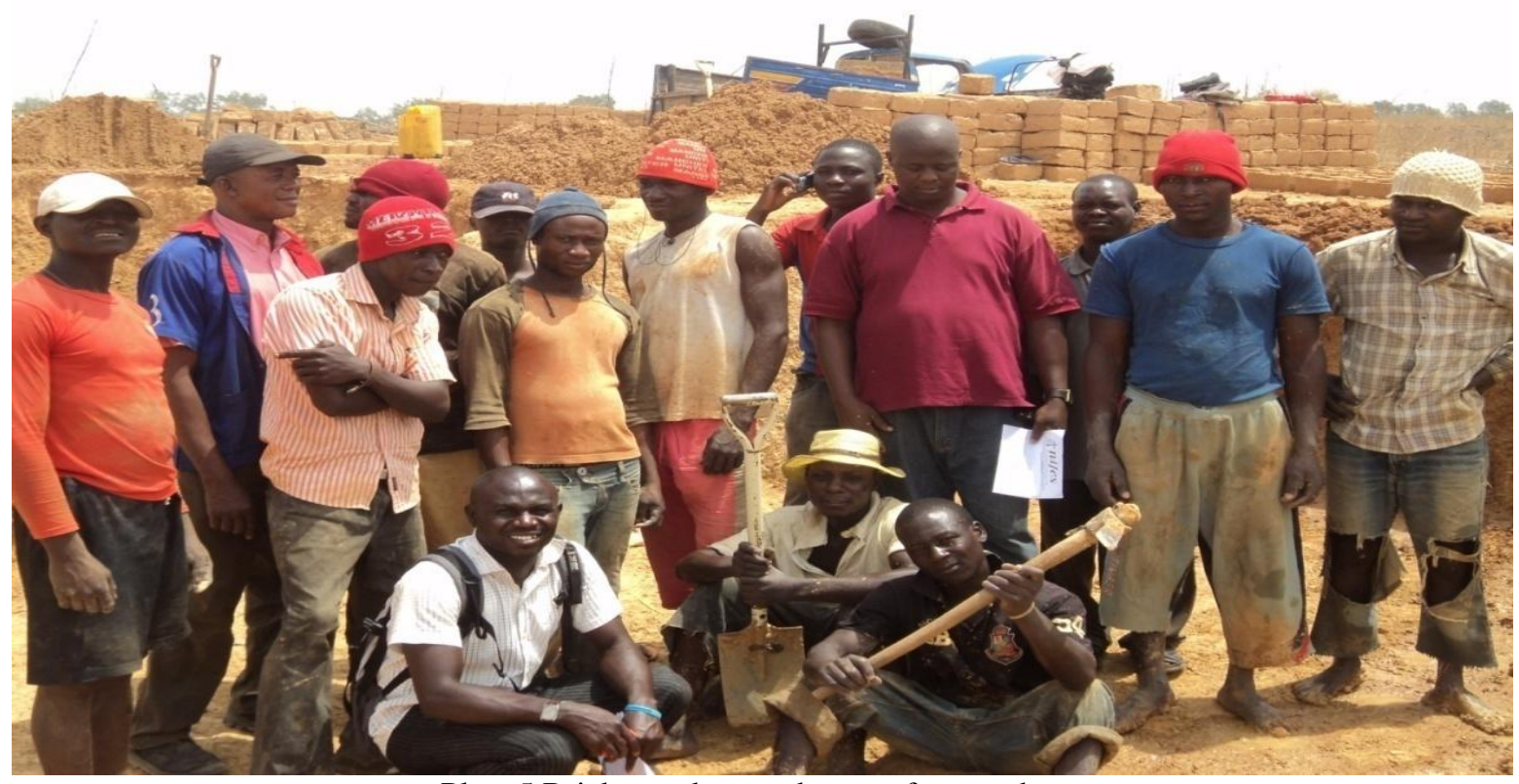

Plate 5 Bricks workers and team of researchers. 


\section{ii. Structures/Residential Houses Built From Brick Made From Topsoil Excavated}

Plates 6 to7 illustrates various residential houses built with clay soil excavated from the topsoil within and between community open spaces.

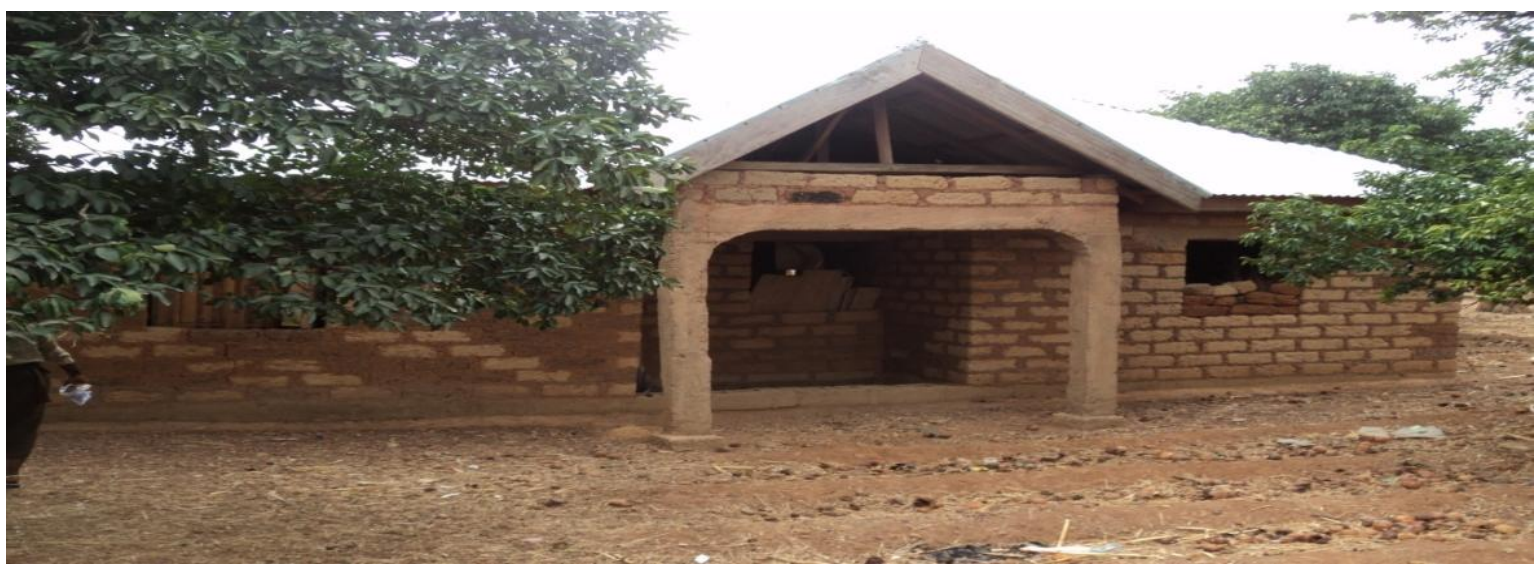

Plate 6. Residential house made with $100 \%$ laterite soil

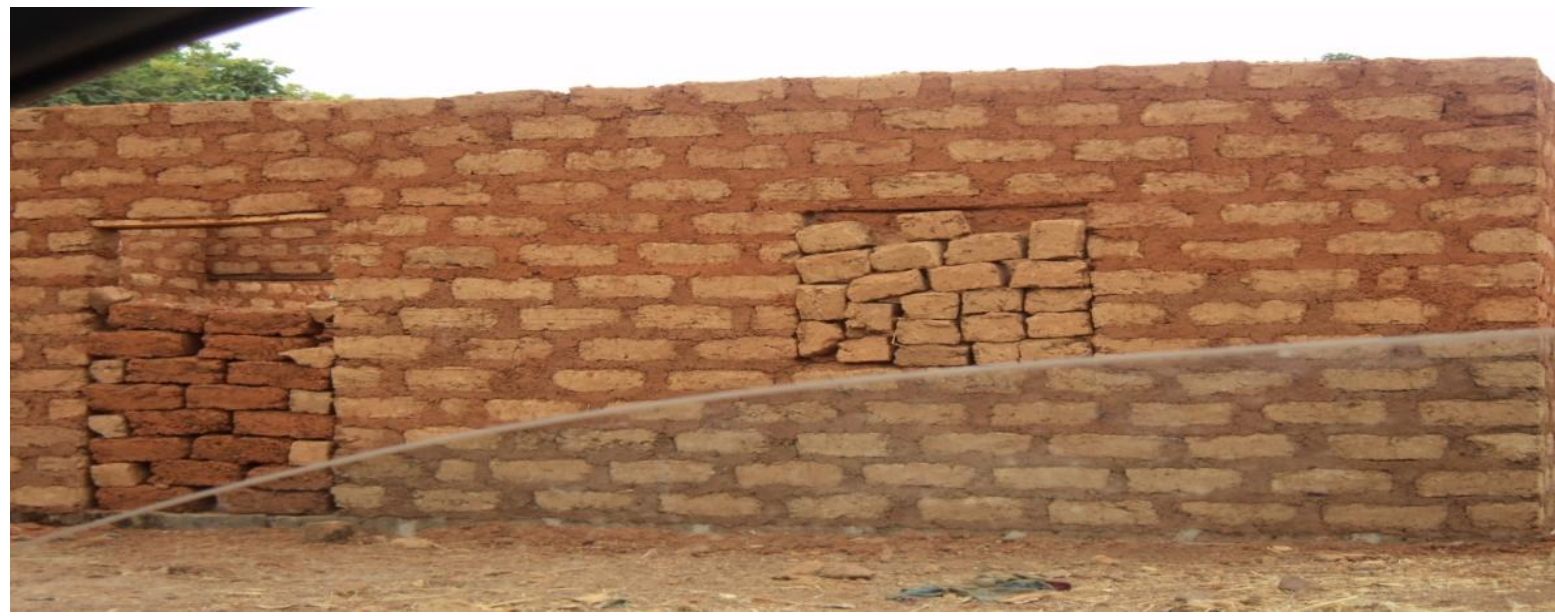

Plate 7. A house under construction

iii. Mining Sites and Gulches Pots Created in The Process of Searching for Precious Stones

The foremost devastating activity in this area is the precious stone mining this is taking serious pealing effect on the community arable land is pictorially depicted in Plates 8 to 10

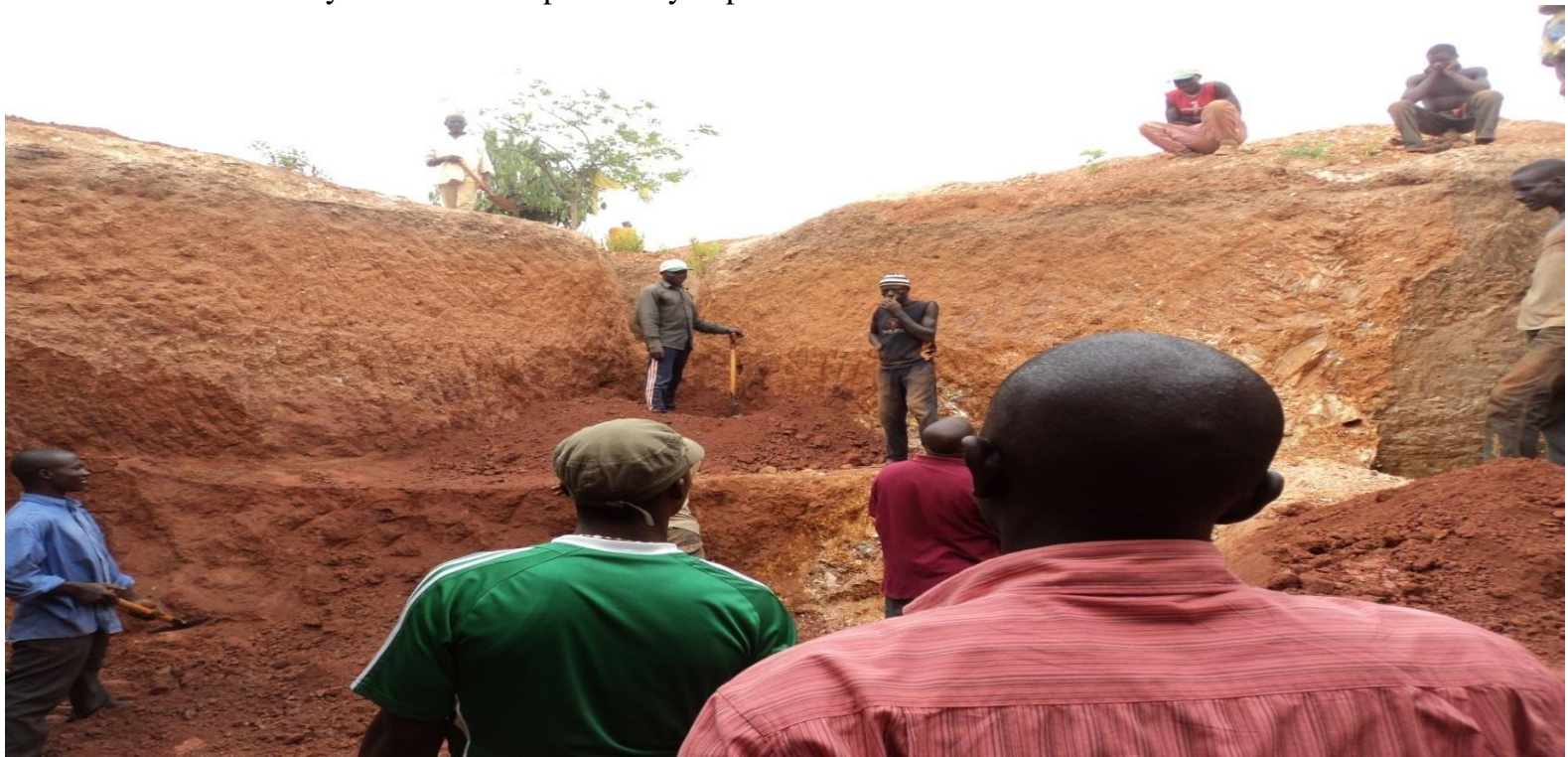

Plate 8. Ongoing precious stone mining site 


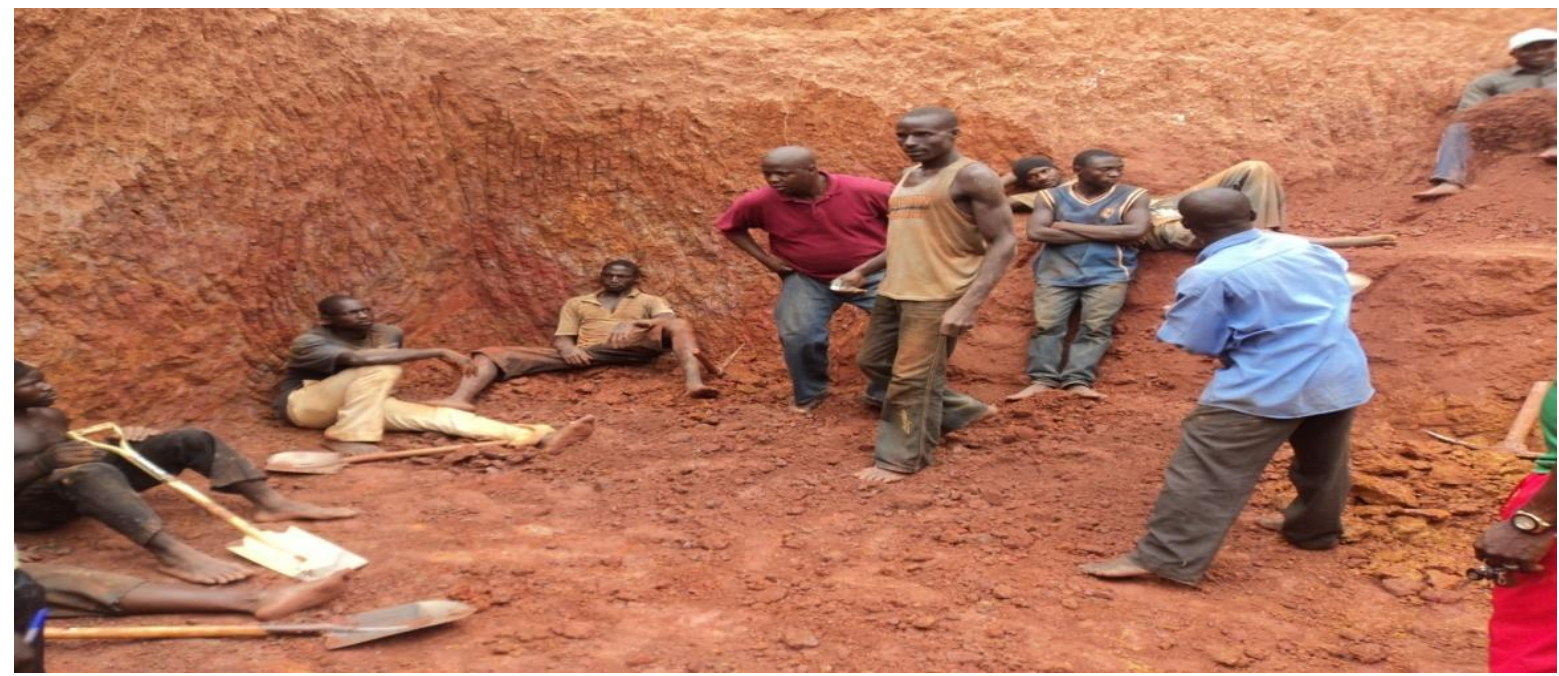

Plate 9. Another stepwise mining point of $25 \mathrm{ft}$ depth and 120 width

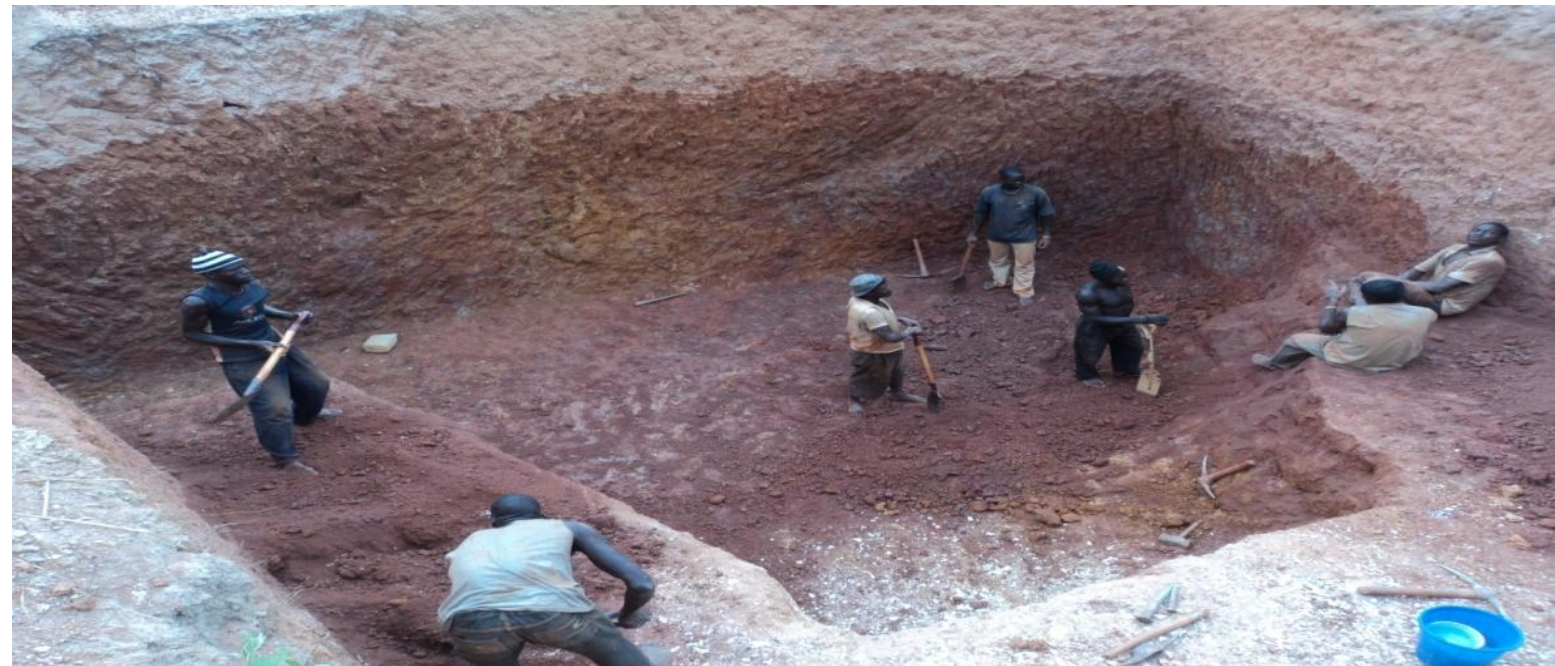

Plate 10. Third group of excavators dredging the soil for precious stone

iii. Externalities and Improvised Land Areas

The immediate adverse effects of aforementioned human activities on the soil in section $\mathrm{i}$ to ii is shown is shown in Plates 11 to 19, while Plates 15 to 19 illustrates and describes typical examples of abandoned mining sites that have becomes habitation for reptiles especially snakes and other dangerous animals as shown in Plate 15)

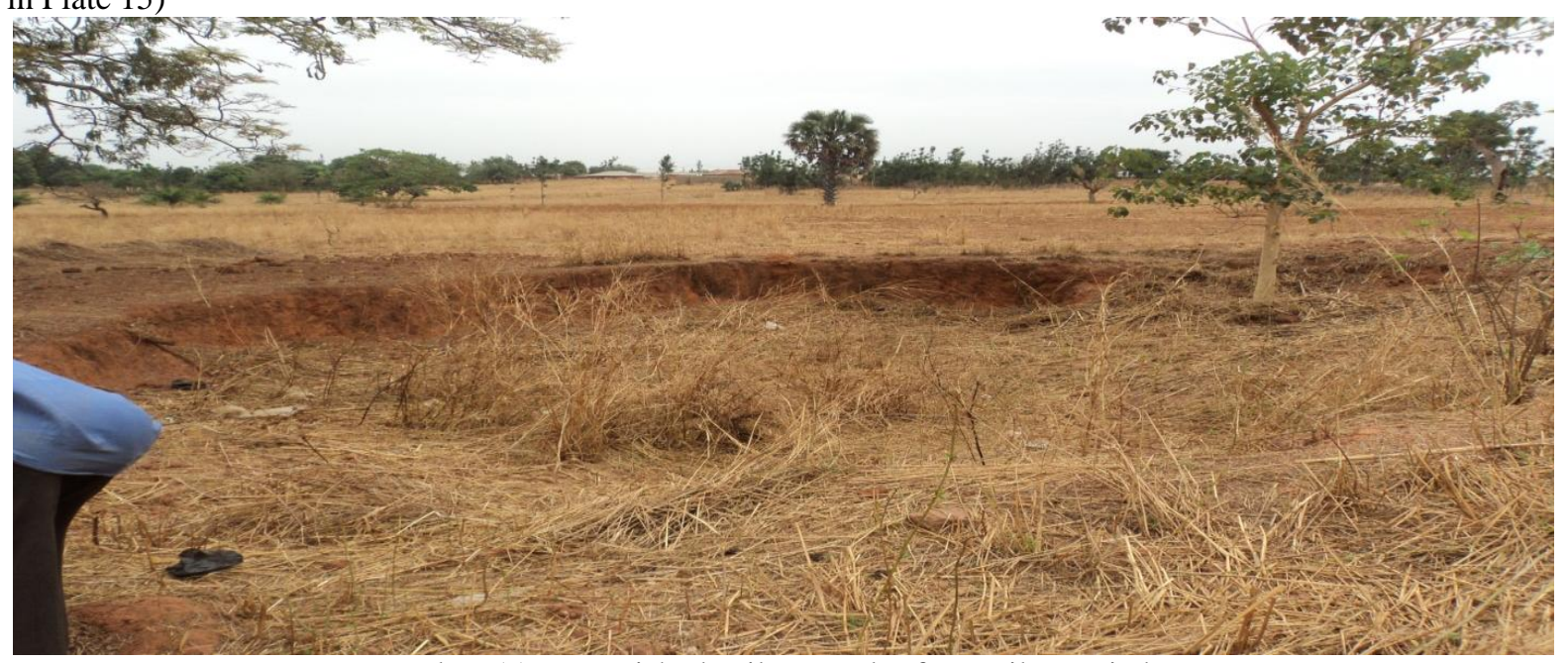

Plate 11. Impovished soil as result of topsoil quarried 


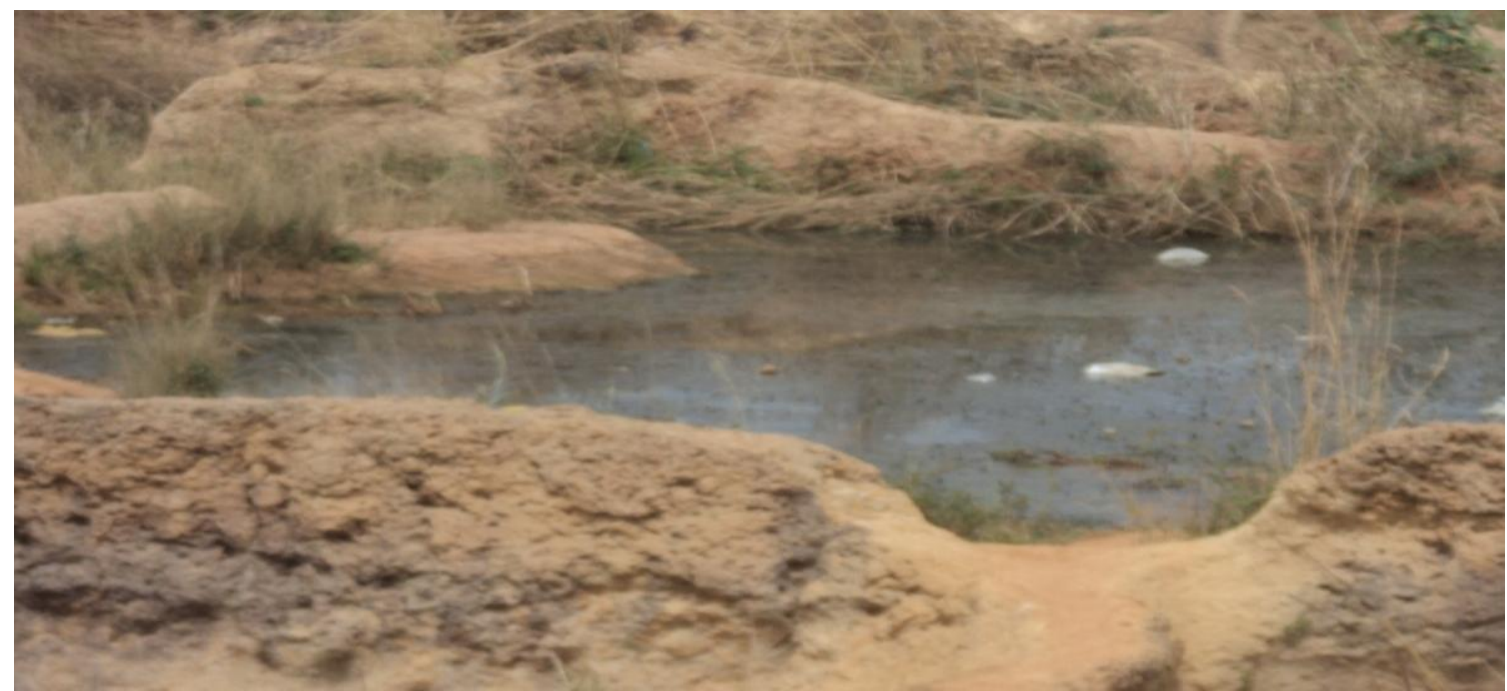

Plate 12. One of the several ponds where Mosquitoes are breed

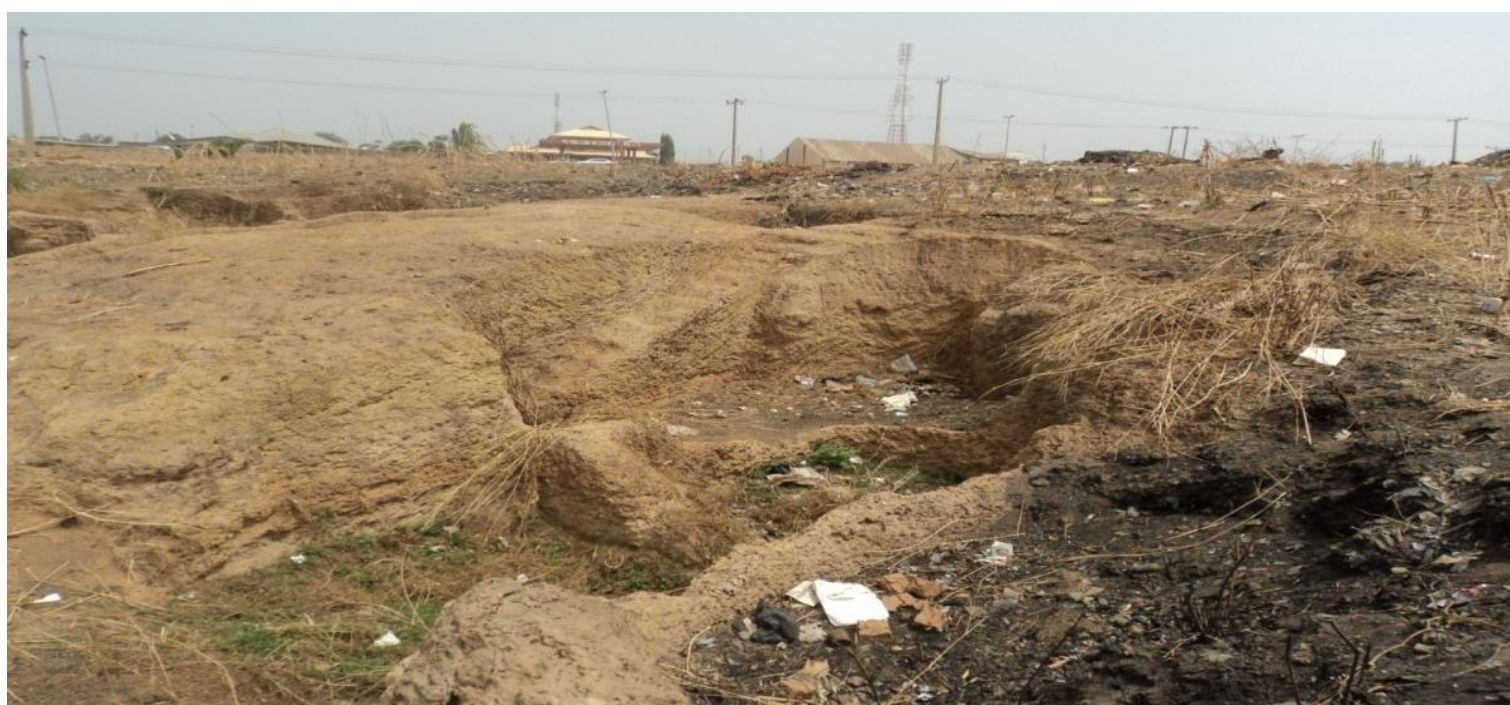

Plate 13 Example of abandoned Mining Site

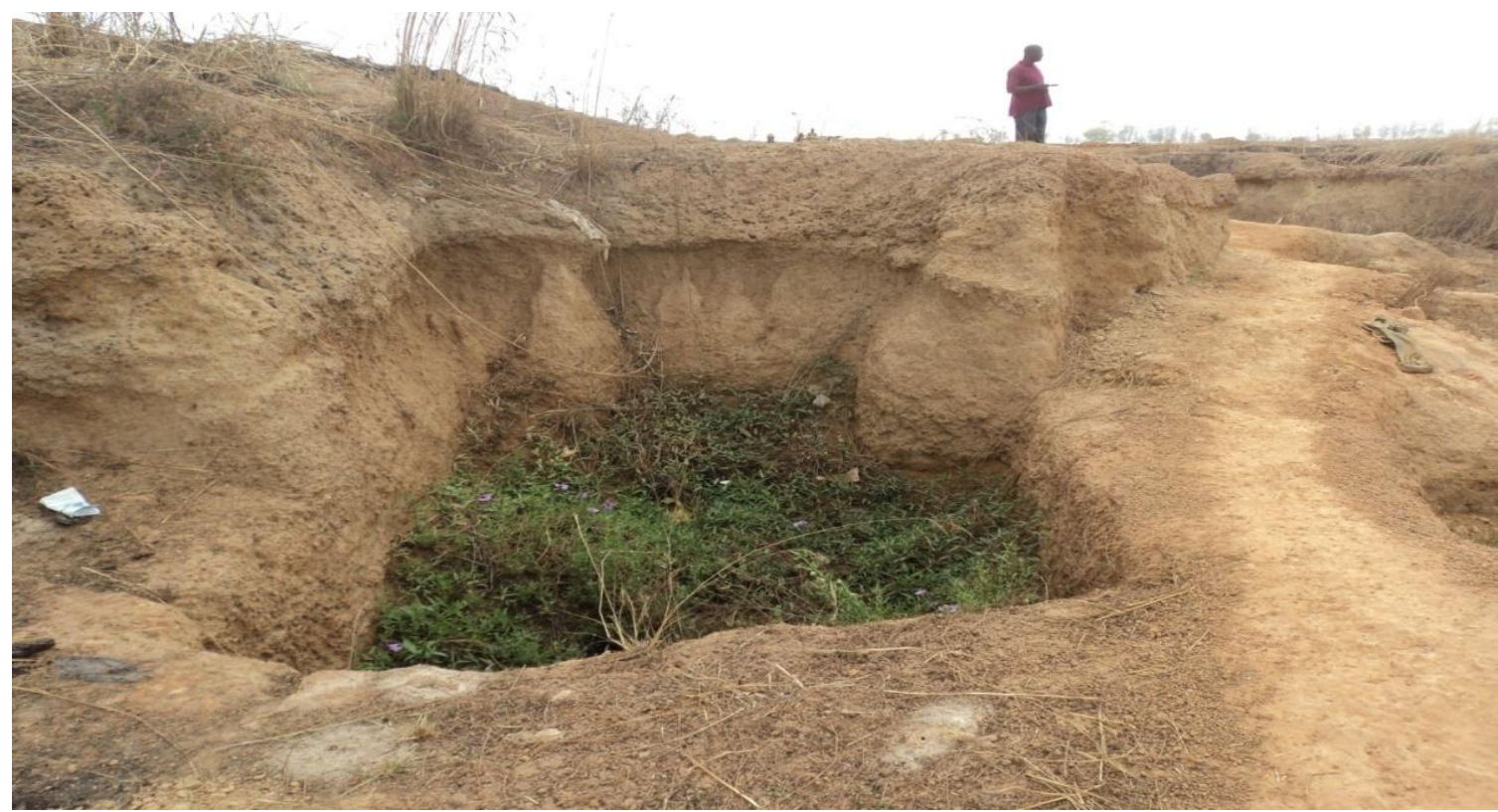

Plate 14.Artificial gully area aftermath of excavations in the nook and crannies of the community 


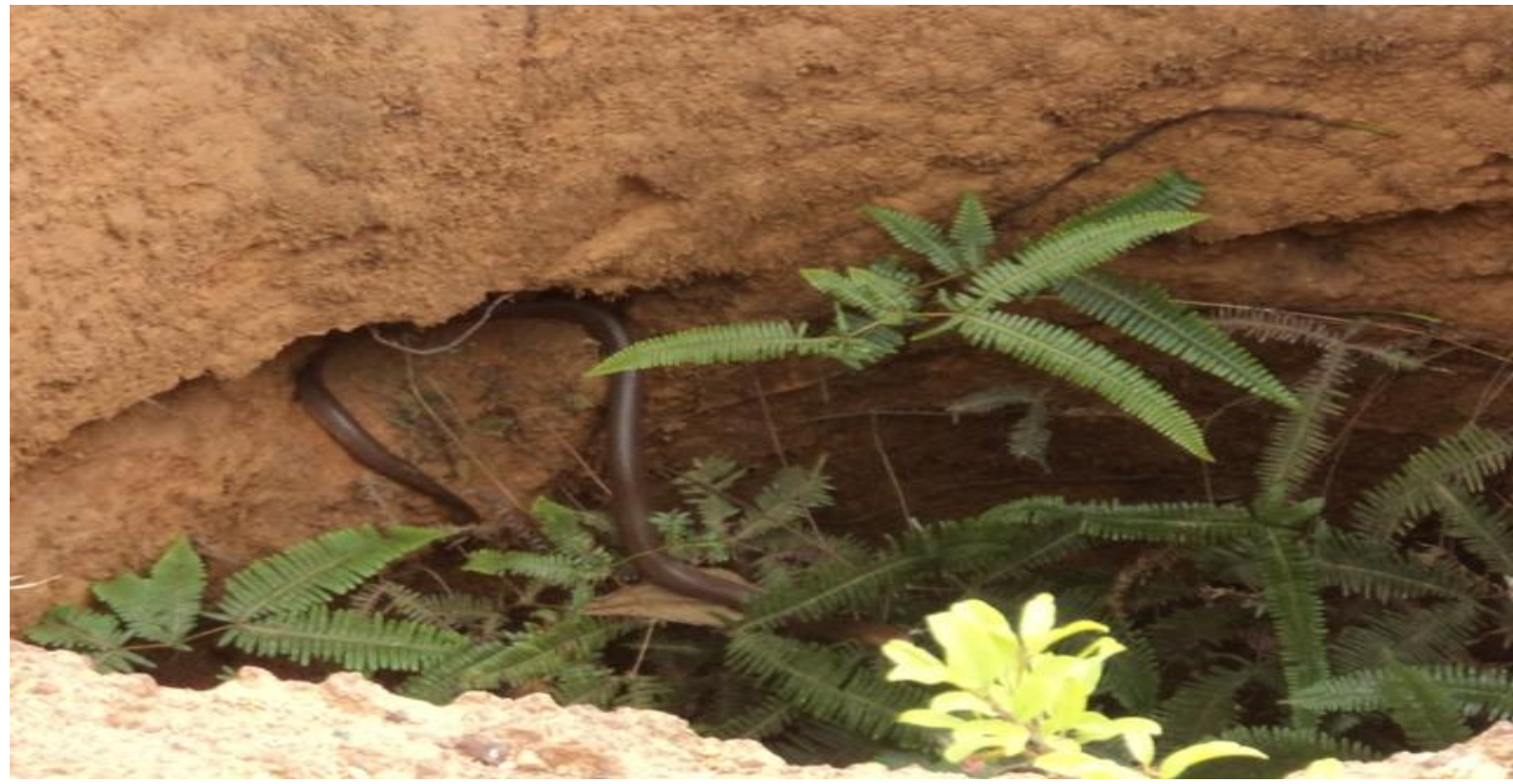

Plate 15. Foxhole Development

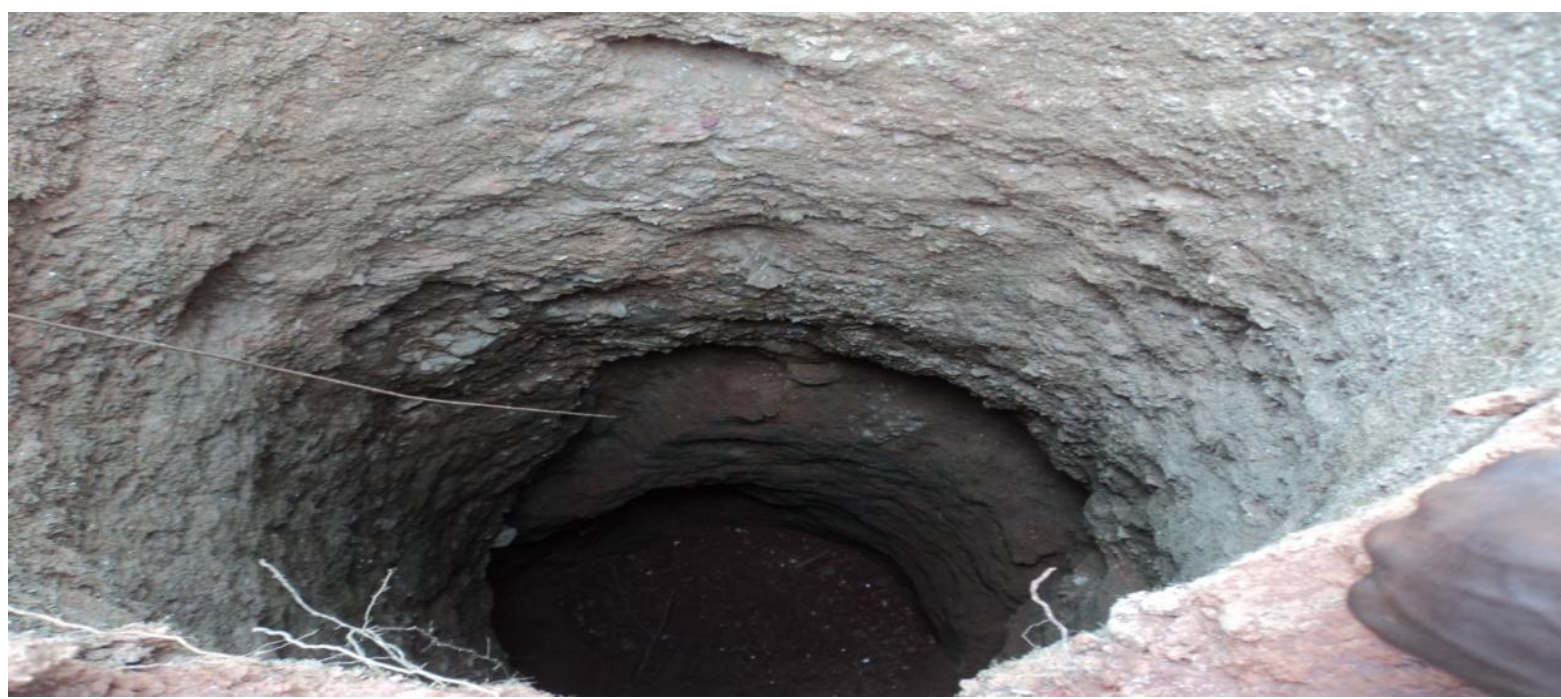

Plate 16. Bunker

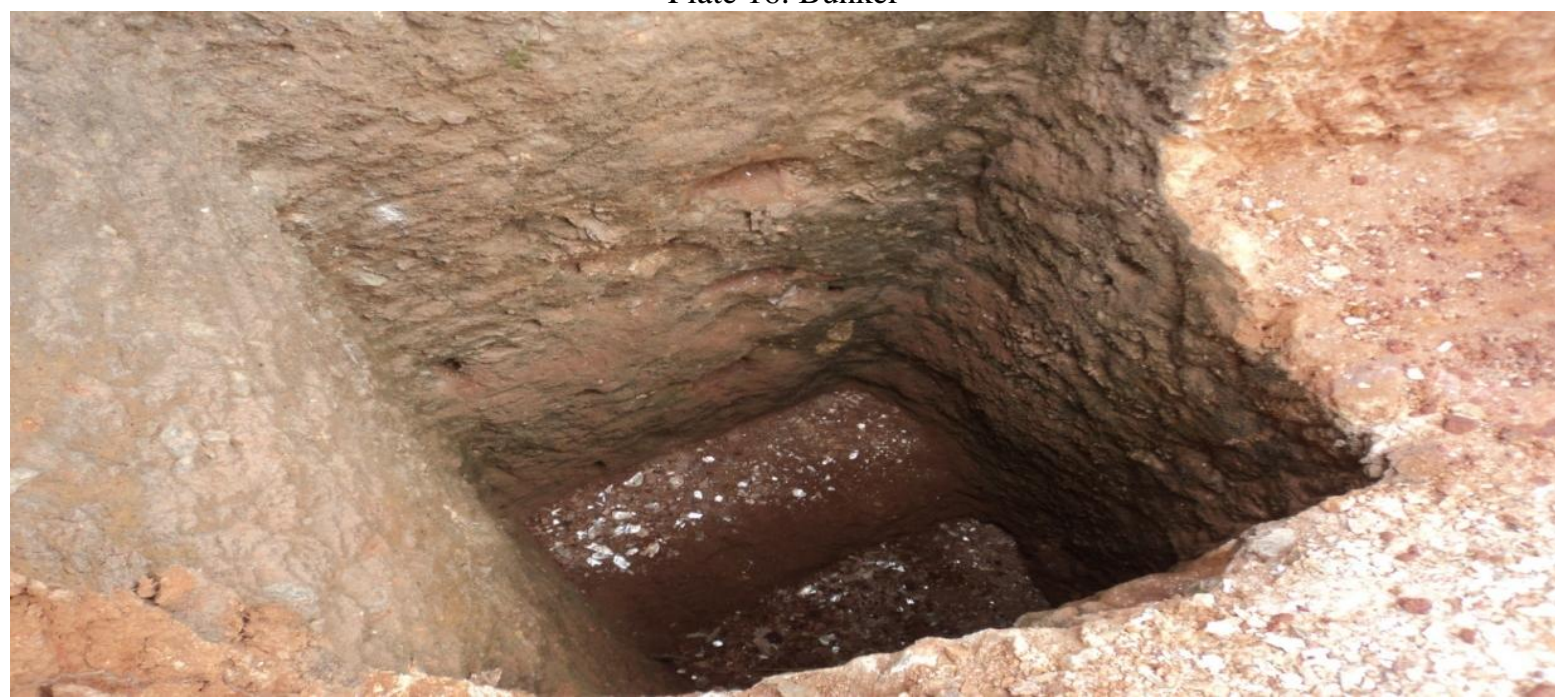

Plate 17. Trench 


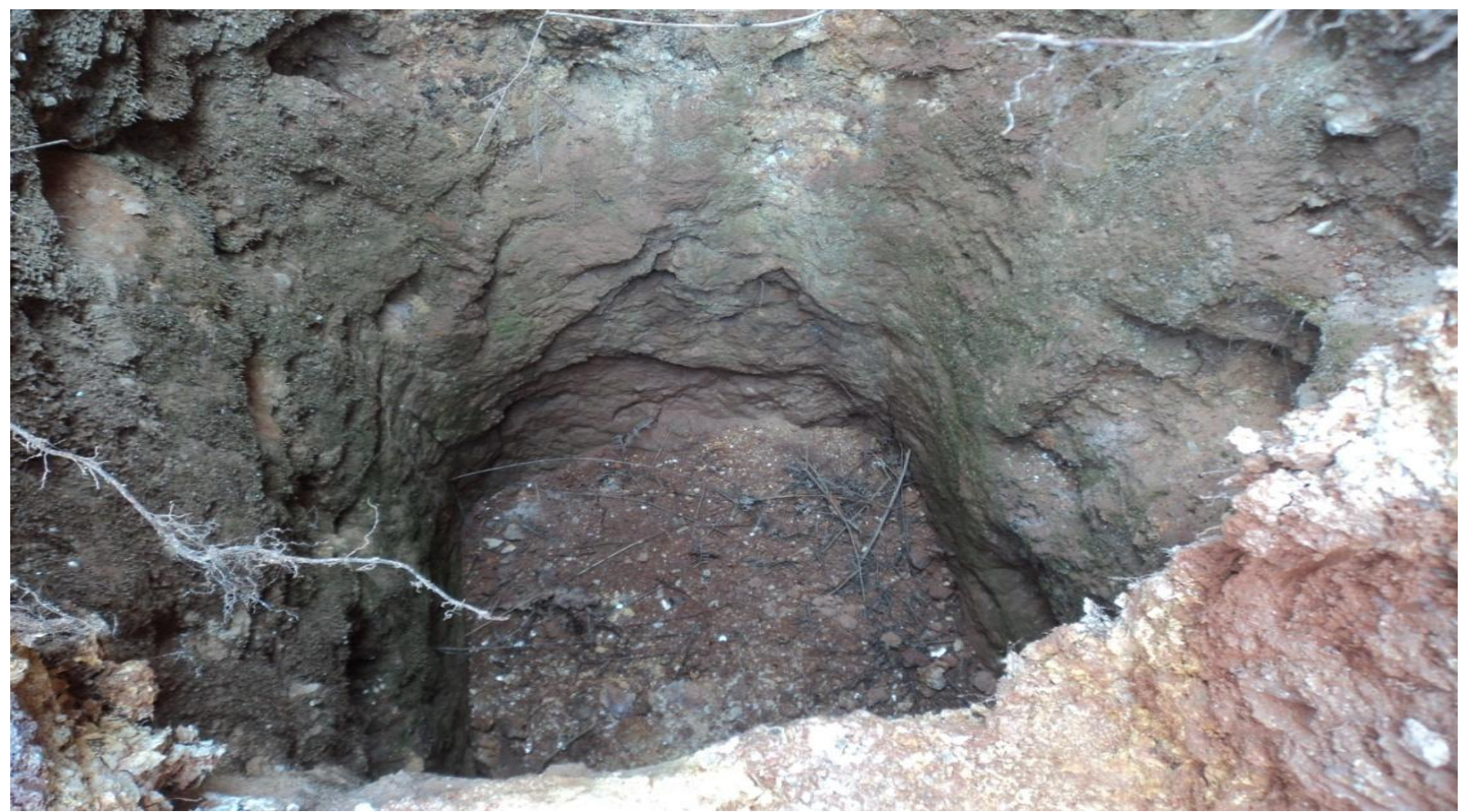

Plate 18. Dith

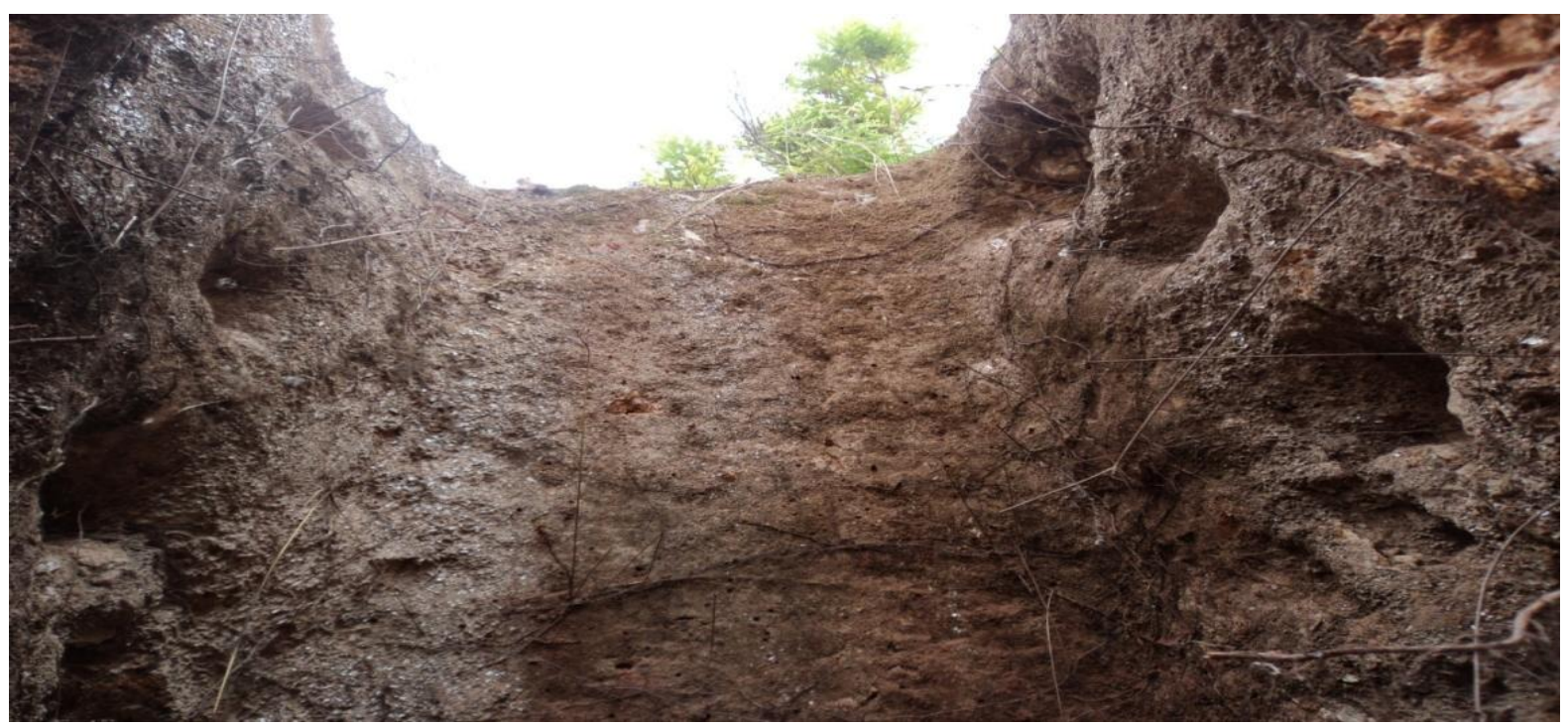

Plate 19. Dugout

\section{Discussions}

Two main reasons have been identified as the root causes of land degradation processes in Fai community, these are: first, excavation of lateritic component of the soil were used for making local bricks which serves as a source of cheap raw material for building residential houses, and second, which is most important in this discourse is the digging of the earth crust for precious stones which also serves as raw material for industrial uses such as making and minting of jewelries.

The study discovers that from the bricks making, some of community members earned their daily income either as workers in the local bricks making sites as labourers involved in digging the lateritic portion of the soil; others fetch water for mixing of the laterites, some engages in transportation of bought bricks molded to building sites; other sets participate in loading and off-loading of finished bricks, while other people engaged family member to work for the production of bricks from land-holdings and use in the construction of their residential houses. For the mining of precious stones, a lot of young men are involved in dredging them. The precious stone is highly valued and attract more profit. But the process has more devastating effect on the environmental sustainability because of depth into the lithosphere and horizontal space coverage. 
These activities, though serves the immediate and basic needs of the people but poses a critical challenge to ecosystem and human livelihood survival in the nearest future. From the assessment the topsoil excavation has covered almost $60 \%$ of arable land space in Fai community and its immediate environs. Investigation further reveals that farming is the mainstay economic activity of the people which involves cultivation both at upland and fadama of the following crops: Millet; Ginger; Rice Sorghum and Acha, some of the people keep livestock such as Cow; Sheep and Goat. Other sources of livelihood identified also include: petty trading of detergents and provisions, bicycle and motor bike repairing and transport services, all these economic activities are carried out at subsistence level.

It is pertinent to note that in this area Ginger (Zingiber official lRoscoe) is the highflier crop, the area is known for and are cultivated extensively by the people. The crop requires an abundance of rainfalls above $1000 \mathrm{~mm}$ that should be well distributed over a period of six to eight month, with temperature range from 23$35^{\circ} \mathrm{C}$. Ginger is also a plant that thrives in hot and moist climate with abundant shade and in rich, well drained loamy soils with plenty of manure. These requirements for the crop to do well are already facing unprecedented threat from other simily profitable activities particularly precious stone mining and laterite excavation. Also, the unprecedented rainfall of this year predisposes the dug tunnels and ponds in the area to unimaginable flood which further hampered productivity of agricultural crops.

The occupation of the people is threatened by the intensive loose of quantity and quality of cultivable land for agricultural purposes, this is happening through loss of silting of soils which has high potential of increasing salinization and alkalinzation of soils, as a result of being susceptible of the area to agent of denudation. Although soil is considered as a renewable resource, however, the time frame necessary for it formation is much too long to compensate for losses currently taking place in Fai communities. It is pertinent to note that once soil has been destroyed either by natural phenomena, or due to human actions, it may take as long as 7,000 years to reform and provide an adequate depth of topsoil to sustain the agricultural activities of the people (Anderson, 2006). Researches further indicate that under natural conditions, soil may be formed at the rate of about one $\mathrm{cm}$ at more than 400 years. Thus, the formation process accelerates considerably under normal agricultural practices, when it takes approximately 3.75 tons of topsoil is formed/ha/year (Anderson, 2006). In contrast, current loss of topsoil from mining activities, excavation of topsoil for the purpose of extracting the laterite portion for building and essence of property ownership are at indescribable proportion in this area.

It is also, necessary to note that light farming processing activities such as clearing of natural vegetation, weeds, and crops for seedbed preparation leaves the soil with sparse plant cover or root mass to protect it from wind and rainwater impact and surface water flows. The result also cause loss of topsoil and plant nutrients compared to total removal and buried of humus structure and content of the soil that is currently going on in Fai Communities. This poses potent and inherent danger to future agricultural activities and community sustainability.

In conclusion, the various pictorials have elicits significant problems in virtually all the nooks and crannies of the community land space are cover by human induced soil degradation. The loss of arable land in this area has been caused by a number of factors, many or most of which are tied to human desire for survival and development. The primary causes are deforestation by indiscriminate excavation of the topsoil for residential building purposes and intensive and overexploitation of the same for precious stone mining. This development is gradually setting in desertification process unnoticed and unconscious of, for the fact that nondesert area starts to exhibit the characteristics of a true desert as shown in the externalities plates calls for caution according to early warning signals identified by the United Nations (1996)

The scenario in Fai and its immediate environs can be inferred as representation of fast desertification processes going on the countryside in Nigeria. Therefore a pragmatic and people driven and bottom-up intervention is sine qua non. We need to promote greater collective action that is alleviation of land degradation depends not only on the motivation of individual stakeholders, but also on the action of the whole community, and this makes it more challenging.

The alleviation of land degradation cannot succeed without the participation and collective action of all stakeholders mostly because, the degradation of resources spreads easily from one plot to the other and from one area to the other; and attempting to alleviate land degradation in a localized area will be counterproductive if the whole landscape is not taken into consideration. As such, there is a need to adopt a coordinated approach so that most stakeholders are included in the programme and, most important, are provided with a choice to organize themselves. This is especially true as farming and rural development are at least partially collective businesses, meaning that rural dwellers usually tend to adopt similar resource management practices and to support each other by such means as labour sharing and marketing. Advocacy and sensitization of the people of impending danger to unborn generation as result of present action is quite necessary and more importantly, participatory approach of reclaiming the land through acquisition of cash and economic trees and crops will serve as palliative measure. This can be done through vocational training and life building skills schemes driven to sustain the intervention and backfill the immediate income generation for the people at short run. However, 
this work will not be completed if it failed to acknowledge Care and Action Research, Kaduna (CaRE-NGO) who invited as a lead researcher that facilitated the research investigation also her international partners of Global Environment Facility/Small Grants Program of United Nations Development Programme (GEF/SGP/UNDP) that financially supported the study.

\section{References}

[1] Anderson, K., 2006; Reducing Distortions to Agricultural Incentives: Progress, Pitfalls and Prospects. American Journal of Agricultural Economics 88(5)

[2] Bruinsma, J., ed. 2003; World agriculture : towards 2015/2030 : an FAO perspective. FAO ;

[3] Earthscan: Rome ; London.

[4] Cassman, K.G. and P.L. Pingali, 1995; Intensification of Irrigated Rice Systems: Learning

[5] from the Past to Meet Future Challenges. Geo-Journal 35

[6] Eswaran, H., R. Lal, and P.F. Reich, 2001; Land Degradation: An overview. in Responses to

[7] Land Degradation. 2nd. International Conference on Land Degradation and Desertification. Khon Kaen, Thailand: Oxford Press, New Delhi, India.

[8] Evenson, R.E. and D. Gollin, 2003; Assessing the Impact of the Green Revolution, 1960 to 2000. Science 300

[9] FAO. FAOSTAT - Agriculture. 2007; [cited 13 March 2007]; Available from: http://faostat.fao. org. 11th June 2011

[10] Henao, J. and C. Baanante, 2006; Agricultural Production and Soil Nutrient Mining in Africa.

[11] Implications for Resource Conservation and Policy Development. International Fertilizer Development Center: Muscle Shoals AL.

[12] Kim, K., B.L. Barham, and I. Coxhead, 2000; Recovering soil Productivity attributes from

[13] Experimental data: a statistical method and an application to soil productivity dynamics. Geoderma 96

[14] Nigeria Demographic and Health Survey, 2009; National Population Commission Publication, Federal Republic of Nigeria, ICF Macro, Calverton, Maryland, USA

[15] National Population Commission, 2006; Final Report, National Population Commission Publication, Abuja, Nigieria

[16] Oldeman, L.R., R.T.A. Hakkeling, and W.G. Sombroek, 1991; World map of the status of

[17] Human-induced soil degradation: An explanatory note. Wageningen and Nairobi: 11International Soil Reference and Information Centre and United Nations Environment Programme.

[18] Scherr, S.J., 1999; Soil Degradation. A Threat to Developing-Country Food Security by 2020? International Food Policy Research Institute: Washington DC.

[19] Population Reference Bureau International, 1995; Population Bulletin a Publication of the Vol.

[20] 50, No. 1

[21] Sjaastad, E. and D. Bromley, 1997; Indigenous Land Rights in Sub-Saharan Africa:

[22] Appropriation, Security and Investment Demand. World Development 25 (4)

[23] United Nations., 1996; Convention to Combat Desertification, 1996, How Much Land Can Ten Billion People Spare for Nature United Nations Publication. 